\title{
Mechanisms to control grape erineum mite Colomerus vitis Pgst. in organic, biodynamic and traditional vineyards of the Crimea
}

\author{
Marina Volkova*, and Yakov Volkov \\ Federal State Budget Scientific Institution All-Russian National Research Institute of Viticulture and \\ Winemaking Magarach of the RAS, 31, Kirova str., 298600, Yalta, Republic of Crimea, Russia
}

\begin{abstract}
Eco-oriented organic and biodynamic vineyards no longer relying on pesticides in protection schemes are indicative of a current trend in grape and wine growing of the Crimea. In this connection, new solutions to reduce pests and diseases have to be sought for, and monitoring which includes both eco-faunistic research and prediction of the numbers of phytophages is becoming of primary importance in the system of control of injurious species on grapes. A wide distribution of grape erineum mite Colomerus vitis Pgst. was registered in the bearing study vineyards on the South Coast of the Crimea and in the south-west of the Peninsula though its economic damage is negligible. The risk of the detrimental effect of the mite in the young study vineyards during the first two years after planting was stated. Key mechanisms to regulate the numbers of $C$. vitis in the organic and biodynamic study vineyards were revealed, such as winter pruning of canes as part of farming practices, application of sulfur to control Erysiphe necator, and natural regulation by indigenous predatory species of mites and other insects.
\end{abstract}

\section{Introduction}

Eco-oriented organic and biodynamic farming no longer relying on pesticides and mineral fertilizers to sustain natural self-regulated processes in a biocenosis is becoming a trend of the global agroindustrial production. A growing consumer demand for eco-products and a strong urge to diminish negative anthropogenic load on the ecosystem of our Planet are underlying factors of this trend $[1,2]$. At present, a total of 186 countries develop organic farming which accounts for 71.5 million hectares (about one percent of the global area of agricultural lands. Australia has 35.6 million hectares of organic lands [3] while India leads in the number of organic producers, followed by Uganda and Ethiopia [4, 5]. In Russia, organic agricultural lands account for more than 674370 hectares [6]. Organic farming is good for restoration and improvement of soil fertility, which opposes to soil degeneration and extinction of biological diversity. Growing of organic products is safe for human health and important for public health care. Updated statistics indicate a dramatic increase in areas of organic vineyards, making already eight percent of the global organic production $[3,7]$.

\footnotetext{
* Corresponding author: frog_marisha@list.ru
} 
In addition, nonuse of pesticides with their negative effects on yeast strains present in the soil and on the surface of the berry may help develop conditions for the production of quality 'terroir' wines $[8,9]$.

Unstable effectiveness of protectants authorized in organic production is a key factor that hampers growing of organic products, the more so under conditions of intense development of injurious organisms. The highest risk of yield losses is associated with conversion vineyards during the first years of transition from the traditional chemical protection system to the organic approach. To be mentioned is an increasing need to apply modern effective farming practices and agricultural technologies characteristic of organic viticulture and adapted to definite agrocenoses. All this leads to temporary reduction in productivity by 30 to 50 per cent, and that is why the organic approach should be developed by producers who do not use intense methodologies [6]. Predicted losses will be compensated for by higher prices of organic products. The reasonable prices of organic wines and grapes on the global market are by five to 30 per cent higher than those of traditional products $[7,10]$.

The Crimean Peninsula is a leading grape and wine growing region of Russia. In 2020, its area planted to grapes was 20.09 thousand hectares, and the majority of vineyards were bearing. Development of organic viticulture in the Crimea should especially be encouraged because of the region's importance as a recreation and tourist center. Many Crimean vineyards are located within water-protection territories and in proximity to recreation zones, which urges the need for transition from the traditional culture to the ecologically safe approach. Modern protection systems applied in the Crimean vineyards aim, as a rule, to control the agents of oidium Erysiphe necator Burill., mildew Plasmopara viticola Berk., phytophagous mites of the family Tetranychidae (Schizotetranychus pruni Oud., Tetranychus urticae Koch.) and grape moth Lobesia botrana L.

The pattern of domination in complexes of phytophages, emergence of new dominant species and expansion of natural habitats of thermophilic invasive species to more northern territories are, by all means, affected by climatic changes and changes in the line of protectants to be applied. Thus, an increased heat supply index during the vegetation season and a somewhat higher air humidity index registered in the Crimea are part of the current trends of climatic changes [11], the duration of the seasons of the year also becoming different. Since the 1980s, the South Coast of the Crimea has seen a trend for an earlier beginning of the vegetation season, resulting in a higher risk that vegetating vines may be injured by late frosts, for later dates of the first autumn frost, and for a longer length of the warmest period in summer when the temperatures are higher than $20^{\circ} \mathrm{C}$ [12]. As predicted for the coming decades, the average temperature of the vegetation season in the south-west of the Crimea (Sevastopol region) will continue to grow, up to $13.8^{\circ} \mathrm{C}$ and higher [13]. Another trend is that extremely low winter temperatures become more frequent. During the period of 2000-2017, the frost hazard index varied over a larger range, and very cold temperatures were registered more often than in 1985-2000 [11].

New eco-oriented organic and biodynamic vineyards no longer relying on pesticides in protection schemes are becoming part of grape and wine growing of the Crimea. This implies, as a consequence, possible changes in the complex of dominating species of pests and the need for new solutions to control their numbers. That is why monitoring which includes both eco-faunistic research and prediction of the numbers of phytophages is becoming of primary importance in the system of control of injurious species on grapes.

Grape erineum mite Colomerus vitis Pgst. of the family Eriophyidae (eriophyid mites) is a minor yet permanent phytophagous species inhabiting modern Crimean vineyards. For two centuries, up to the beginning of the $19^{\text {th }}$ century, the mites of this family were described as the larvae of flies in galls formed by fungal metabolism and, later, as the larvae of spider mites [14]. Signs of infestation by C. vitis appear in the beginning of the 
vegetation season, in the stage where two or three leaves become detached and cane growth takes place. The response of a vine consists of leaf parenchyma abnormal growth in the form of swellings (erineums), felty inside, on the upper surface of the leaf [15]. The mites do not invade new expanding leaves and continue to feed on those already colonized until the tissue in the erineums dries, and then move to younger leaves of the next tier or to lateral leaves. Flower buds, stems and fruit stalks may also be injured if the mite's numbers are high. Since spring, stunted growth and shorter internodes of canes injured by the mite are common. During the vegetation season, bad injuries slow down lignification, reduce sugar and alter levels of stress-related substances [16]. The damage by the mite is local, though sometimes the insect may cause considerable losses of yield. Besides, vines are weakened by winter frosts, and this increases the pest's injuriousness [17].

The mite winters in colonies of five to 200 and more individuals, rarely singly, under the upper scales and in the felt of primary and reserve buds, depending on infestation levels of vines during the vegetation season. When the level of infestation is high, colonies of the mite consisting each of 1000 individuals may also be found under the peeled-off bark at the base of the buds. The mite occupies the upper leaf tier and is especially noticeable on the first expanding leaves, especially in young one-year-old plantings, being a frequent concern of grape growers.

The goal of this study was to investigate the current status of the $C$. vitis population and the distribution of the pest on European grapes in organic, biodynamic, conversion and traditional vineyards of the Crimea. Another goal was to discover possible mechanisms to control the pest's numbers.

\section{Material and methods}

Ecological peculiarities referring to the distribution of $C$. vitis were examined over the period 2013-2020 on bearing and young vineyards (aged one to seven years and older) with different systems of culture (organic, biodynamic, conversion and traditional vineyards) in different grape and wine growing regions of the Crimea: on the South Coast (environs of Yalta) and in the south-west of the Peninsula (Sevastopol region, Bakhchisarai region). Phytosanitary monitoring was done during the vegetation season (April-October) on the grapes Riesling, Cabernet-Sauvignon, Pinot noir, Mourvedre, Sauvignon blanc, Kangun and Bastardo magarachskii, using published methods of collection, diagnostics and ecofaunistic research. Single-armed Guyot pruning and bilateral cordon were used (Table 1).

No chemical protectants were used in the eco-oriented organic, biodynamic and conversion study vineyards (NN1, 2, 3, 6-9). A commercial preparation of colloidal sulfur with an acaricidal effect (Tiovit Jet) was a key substance applied in those vineyards following the manufacturer's instructions, at $5-8 \mathrm{~kg} / \mathrm{ha}$ for oidium control. Copper preparations to control mildew were also used in the summer period in the years with abundant rainfalls. In 2020, an additional protectant, Bitoxibacillin, based on a strain of Bacillus thuringiensis was applied to control spider mite on the South Coast (vineyard N2). In the biodynamic study vineyards (Sevastopol region, NN6-9), herbal tinctures and authorized biodynamic preparations for control of pests and diseases were applied each year in addition to the already mentioned sulfur preparation Tiovit Jet.

Chemical protectants were applied each year in the traditional study vineyards for control of oidium, grape moth and spider mite on the South Coast (vineyard N10) and for control of oidium, mildew and a complex of pests in the Bakhchisarai region (vineyards NN4, 5). 
Table 1. The study Crimean vineyards with different systems of culture.

\begin{tabular}{|c|c|c|c|c|c|c|}
\hline $\mathrm{NN}$ & $\begin{array}{c}\text { Year } \\
\text { of } \\
\text { planting }\end{array}$ & Region & $\begin{array}{c}\text { System } \\
\text { of } \\
\text { culture* }\end{array}$ & Variety & $\begin{array}{l}\text { Pruning } \\
\text { system ** }\end{array}$ & $\begin{array}{c}\text { Area, } \\
\text { ha }\end{array}$ \\
\hline 1 & 2018 & $\begin{array}{c}\text { South Coast of the } \\
\text { Crimea }\end{array}$ & $\mathrm{C}$ & Cabernet-Sauvignon & SAG & 1,5 \\
\hline 2 & 2018 & $\begin{array}{c}\text { South Coast of the } \\
\text { Crimea }\end{array}$ & $\mathrm{C}$ & Mourvedre & SAG & \\
\hline 3 & 2019 & Bakhisarai region & $\mathrm{O}$ & Riesling & - & 2,5 \\
\hline 4 & 2016 & Bakhisarai region & $\mathrm{T}$ & Cabernet-Sauvignon & SAG & 0,1 \\
\hline 5 & 2016 & Bakhisarai region & $\mathrm{T}$ & Kaugun & SAG & 2 \\
\hline 6 & 2013 & Sevastopol region & B & Riesling & SAG & 1 \\
\hline 7 & 2008 & Sevastopol region & $\mathrm{B}$ & Riesling & SAG & 1 \\
\hline 8 & 2008 & Sevastopol region & B & Pinot noir & SAG & 3 \\
\hline 9 & 2008 & Sevastopol region & B & Sauvignon blanc & SAG & 1 \\
\hline 10 & 1975 & $\begin{array}{c}\text { South Coast of the } \\
\text { Crimea }\end{array}$ & $\mathrm{T}$ & $\begin{array}{l}\text { Bastardo } \\
\text { magarachskii }\end{array}$ & $\mathrm{BC}$ & 1 \\
\hline
\end{tabular}

* $\mathrm{T}$ - traditional vineyards, $\mathrm{B}$ - biodynamic vineyards, $\mathrm{C}$ - conversion vineyards, $\mathrm{O}$ - organic vineyards;

** SAG - single-armed Guyot, BC - bilateral cordon

Weather conditions over the study period were, for the most part, favorable for vine development. The vegetation season on the South Coast of the Crimea is characterized as arid, especially in spring and summer. The hydrothermal coefficient (HTC) varies from 0.19 to 0.48 , with the lowest values usually observed in July. The vegetation season over the study period had, as a rule, average monthly temperatures higher than the average yearly temperatures by $1.5-3.0^{\circ} \mathrm{C}$ on an average.

The average monthly temperature in the Bakhchisarai region (west premountainous agroclimatic region in the south-west of the Crimea) is $11.6^{\circ} \mathrm{C}$. The coldest months there are January and February, with an average temperature of $-0.3^{\circ} \mathrm{C}$ and an average yearly absolute air minimum of $-4.2^{\circ} \mathrm{C}$. The effective heat sums accumulate most intensely in July and August, with average temperatures of 22.1 and $22.0^{\circ} \mathrm{C}$. The study territory is characterized as an area with an insufficient water supply and a non-uniform distribution of rainfalls over the vegetation season $(\mathrm{HTC}=0.64)$.

The average monthly air temperature in the Sevastopol region (west premountainous agroclimatic region in the south-west of the Crimea) remains positive throughout the year. The coldest month there is February, with an average temperature of $+2.8^{\circ} \mathrm{C}$. The warmest month is July, with an average temperature of $+22.4^{\circ} \mathrm{C}$. On the whole, the winter in the region is mild, and the critical values of the air temperature are extremely rare. The water supply of the area is insufficient. May has the lowest annual amount of rainfalls.

\section{Results and discussion}

Evidence of the long-term phytosanitary monitoring reveals that $C$. vitis is a wide-spread organism which occurs permanently in all of the study regions of the Crimea. Nevertheless, the study vineyards on the South Coast were dominated by spider mites, C. vitis being a minor species. The situation was different in the south-west of the Crimea (Bakhchisarai region, Sevastopol region) where C. vitis dominated in the complex of phytophagous mites, with the occurrence of spider mites only as single individuals. To be mentioned is that Riesling, Cabernet-Sauvignon and Bastardo magarachskii were colonized by the mite preferentially though the injuries were local, accounting for not more than ten per cent of the total leaf area in the bearing study vineyards. Single injuries by $C$. vitis were registered 
on Kangun and Mourvedre and in the multiyear plantings of Pinot noir and Sauvignon blanc (up to 3 per cent of the vineyard's area). The injuries were more noticeable in spring, in the phenological stage where the first two or three leaves expand. When the green vegetation mass became abundant, the percentage of the total leaf area injured by the mite decreased. Onward, rare injuries were found only in the upper leaf tier. This is so because the colony of $C$. vitis develops in an isolated way inside an erineum, until the leaf tissue in it begins to dry (25-30 days). Only then mass migration of the mite to the leaves of a new tier or to lateral leaves starts. Some three migrations of $C$. vitis take place in the south-west of the Crimea, with three or four migrations on the South Coast. Morphological changes of erineum, such as color and density, may serve as indicators of the time when the mite's mass migration begins and it occupies new leaves. At the beginning of the mass migration, the felt of erineum becomes rusty brown and begins to dry (Fig. 1). At this stage exactly, the migrating mites become vulnerable to protectants.

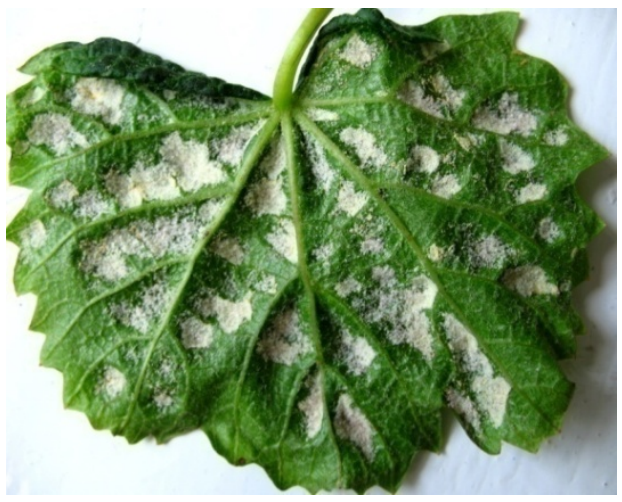

a

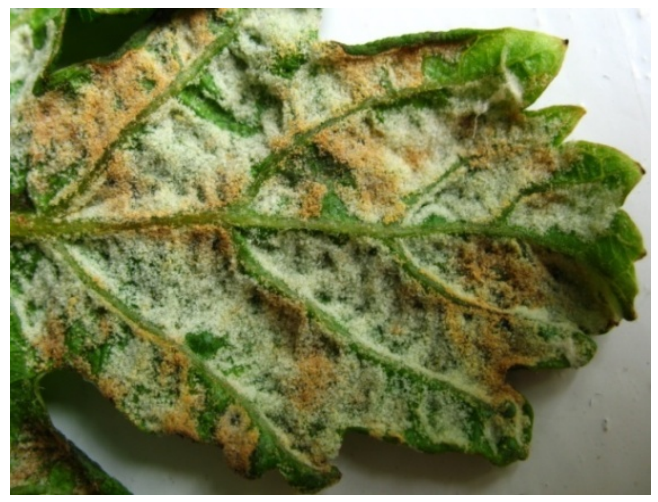

b

Fig. 1. Visual changes of the morphological structure of erineums of $C$. vitis in the study Crimean vineyards $(\mathrm{a}$ - erineums emerge on the leaf following the colonization by the mite; $\mathrm{b}$ - erineums begin to senesce, the color of the felt becoming dark and the leaf tissue beginning to dry.

It was found that the majority of the mite's population in the study vineyards wintered in the felt and under the scales of the buds in the medium and upper portions of the cane. Consequently, the mites were, for the most part, eliminated mechanically during winter pruning when the canes were removed. The first two or three buds from the base of the cane were seldom colonized by the mites (not more than 30 per cent of the population). This makes winter pruning an effective limiting factor in control of $C$. vitis in vineyards.

The numbers of $C$. vitis can be predicted for the next vegetation season depending on pruning systems used in the vineyards (Fig 2). With horizontal bilateral cordon having two or three two-bud spurs, the greater proportion of the wintering mites becomes removed, not more than 30 per cent of the population preserved. 


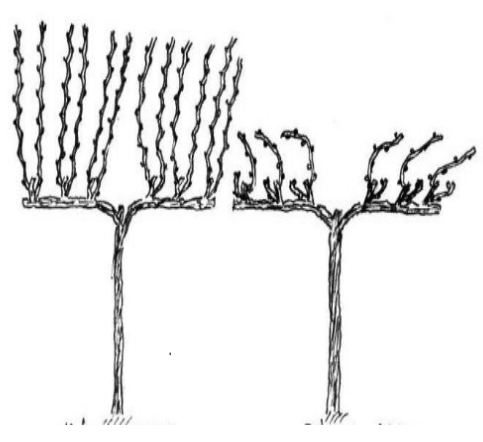

$\mathrm{a}$

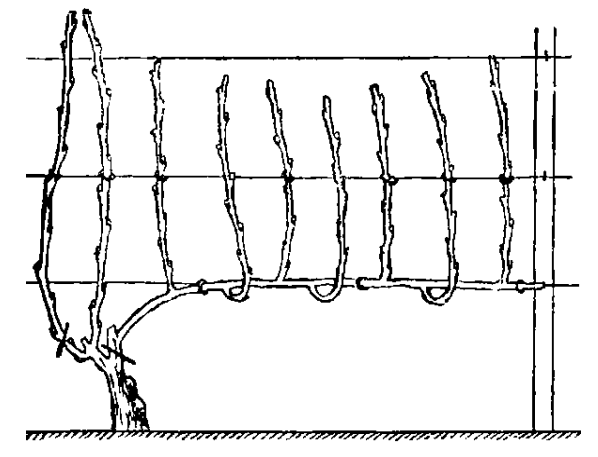

b

Fig. 2. Pruning systems in the study Crimean vineyards: a) horizontal bilateral cordon before and after the canes have been removed; b) single-armed Guyot pruning before the canes have been removed (sites of pruning indicated by bars). Source: https://pro-orehi.ru/wpcontent/uploads/e/5/9/e59cc e0b517c9354dd0c84eae0ca0edc.jpeg

With single-armed Guyot, the fruit cane is preserved whose buds in the medium and upper portions have the highest $C$. vitis colonization potential (56 per cent of buds with potentially high numbers of the mite). Following the first thinning by breaking of the canes, the quantity of potentially colonized canes will be reduced twofold, and a proportion of the mites will die as their migrating ability is low. Nevertheless, potentially infested canes developed from the buds with potentially high numbers of $C$. vitis will remain on the vine. Guyot pruning is popular in Crimean vineyards today, so the mite is going to be a permanent phytophage on the Peninsula.

In the majority of the study Crimean vineyards, the phytosanitary monitoring did not reveal critical levels of the $C$. vitis development with a crossed threshold of economic damage. The situation was different in the young study vineyards (NN1, 3, 4), with a high intensity of visual injuries by the mite during the first two years after planting (up to 40-100 per cent of all leaves on the site). As $C$. vitis winters in the buds and emerges when the leaves begin to expand, infestation of the one-year-old plantings proves that the rootings had been infested in the nursery. The migration of the mite from the periphery of the vineyard must be ruled out due to its low migrating ability. It may be concluded that hot wax treatment of rootings to prevent them from drying during transportation and storage does not eliminate the wintering colonies of the mite and favors its intrusion into new vineyards with planting material. The rootings used in the study were domestic and also from Austrian, French and Serbian nurseries, which shows 'cosmopolitism' of C. vitis. In the one-year-old study vineyards during the first year after planting, the intensity of injuries by the mite in spring was up to 40 per cent of the leaves on a site (NN 1, 3, 4). A year later, the population of the mite continued to increase, with more injuries of the vines (up to 60 per cent in vineyards NN1, 3 and up to 100 per cent in vineyard N4). The rootings in vineyard N4 had been weakened by a badly done grafting procedure, and their growth was stunted. Intense injuries by the mite still deteriorated the depressed condition of the vines, and the increase in terminal growth of the canes during the vegetation season was very low. All buds on the vine were occupied by the mites for wintering, including the first two or three ones from the base of the cane, so the population was not effectively regulated by pruning and could further accumulate. Mass occupation of the leaves by the mites that emerged in spring impaired the leaf photosynthesizing surface, which aggravated the stunted pattern of growth of young canes. Besides, the leaves rolled and fell off prematurely. 
The intensity of leaf injuries by the mite in the remaining young study vineyards (NN1, 3) went down to 20-30 per cent already in the third year after planting. This was promoted by an appropriate grafting procedure and a favorable water regime. Besides, as there were no competing weeds between the rows, the rootings became well established (Fig. 3).

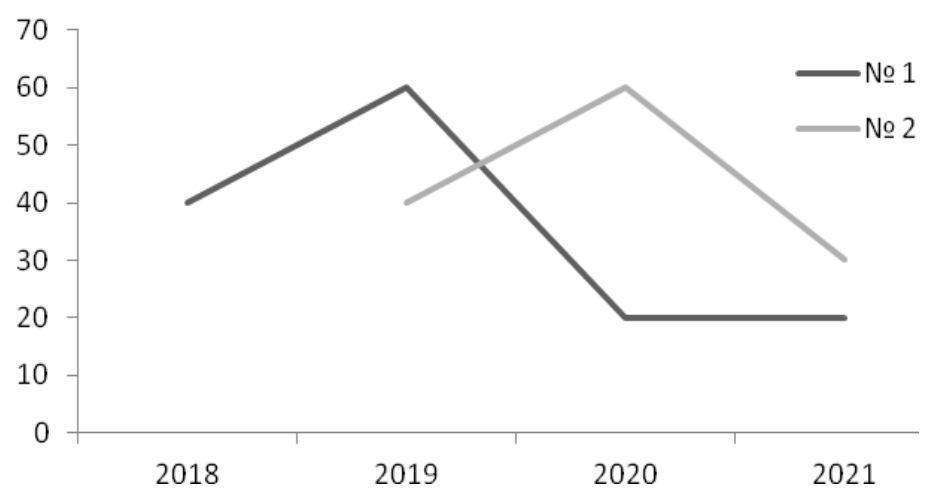

Fig. 3. Long-term dynamics of intensity of leaf injuries by the mite $C$. vitis in spring (relation of the quantity of injured leaves to the total leaf mass, in per cent) in the Crimean young study vineyards (N1 - Cabernet-Sauvignon, planted in 2018, South Coast; N2 - Riesling, planted in 2019, Bakhchisarai region).

The injuries were more noticeable in early spring. Onward, the visual intensity of the injuries went down as the vegetation mass of the vines increased and the leaf area grew larger. The numbers of the mites in the wintering sites also decreased from 67.7 individuals per bud in 2018 to 0.4 individuals per bud in 2020 (vineyard N1), with the numbers of the mite in the bearing study vineyards of 3.4-10.7 individuals per bud (vineyards N6, 7).

In the eco-oriented organic, biodynamic and conversion study vineyards, the $C$. vitis population was regulated both mechanically and by regular application of sulfur in Tiovit Jet with an acaricidal effect as part of measures to control oidium. In those cases there was no need to rely on additional dedicated treatments. In the traditional study vineyards with a system of complex protection, acaricidal preparations also had to be applied.

In addition to mechanical regulation of the $C$. vitis numbers by pruning, natural factors such as natural enemies of the organism (predatory mites and other insects) played an important role in vineyards. Grape agrocenoses of the Crimea are characterized by a 'mosaic' pattern of the landscape architecture. Crimean vineyards are small and often surrounded by natural biocenoses with wild-growing trees and bushes, which leads to a high species diversity of a predatory biota. It is known that wild-growing vegetation in the vicinity of agrocenoses is important for the accumulation and migration of a useful biota and for the stabilization of a vineyard's phytosanitary situation [18].

A number of species of the entomo- and acarofauna were found in associations with $C$. vitis during the vegetation season in the study vineyards. These are omnivorous organisms or preying on definite objects and include predatory mites of the family Phytoseiidae (Typhlodromus cotoneastri Wainst., Phytoseius plumifer Can. et Fanz., Euseius finlandicus Oud. etc.), Stigmaeidae (Zetzellia mali Ewing.), Tarsonemidae, Pronematidae (Pronematus rapidus Kuzn.) and predatory insects such as the midge Arthrocnodax cf. vitis Rubsaamen (Cecidomyiidae), bugs Orius sp., thrips Scolothrips acariphagus L. and Aeolothrips fasciatus L. The solid felt and the shape of the mite's erineums reminding of galls work as a barrier protecting from drastic climatic changes, pesticides and other negative factors of the environment. The microclimate of erineums retains moisture and is favorable for the development of phytophagous and predatory insects. The larvae and pupae of the predatory midge and ovipositions of the abovementioned predatory mites were regularly observed in 
the felt of $C$. vitis erineums in the study vineyards. It may be concluded that erineums of the phytophage $C$. vitis attract predatory species and promote their migration from the periphery of vineyards and from reservations in a vineyard itself.

It was found that predatory mites of the families Phytoseiidae and Stimaeidae often wintered together with colonies of $C$. vitis in the study vineyards, as a rule, under the scales of the first six buds (up to 96 per cent of the total population wintering in the buds). Since they are of larger size, they prefer larger buds at the base of the canes. During winter thawings frequent on the South Coast of the Crimea, predatory mites become active in their wintering sites and may feed in the buds, leading to a decrease in the wintering reserve of the pest. In early spring, when first leaves expand, $C$. vitis becomes the only food source for the predators as spider mites winter in cracks of the bark on the trunks of vines and emerge later, when three to five leaves expand.

The abovementioned species of predatory mites and other insects were widely distributed in all of the study Crimean vineyards. Nevertheless, their numbers were higher in the organic, biodynamic and conversion study vineyards where pesticides were not used. The mites Phytoseiidae and the midge Arthrocnodax $c f$. vitis were the most abundant and widely distributed predatory species that regulated the $C$. vitis numbers during the vegetation season. It is known that larvae of the predatory midge Arthrocnodax vitis Rubsaamen (Cecidomyiidae) are met in association with the mite $C$. vitis on wild-growing vines of Vitis vinifera L. in Spain and on cultured grapes in Iran [19, 20]. Despite regular sulfur application in the organic and biodynamic study vineyards, the predatory mites and the larvae of the midge were abundant and regulated the $C$. vitis numbers effectively.

\section{Conclusions}

Grape erineum mite $C$. vitis was widely distributed in the study Crimean vineyards with different systems of culture. This phytophage is a minor species on the South Coast and dominates in the complex of phytophagous mites in the south-west of the Peninsula. Nevertheless, the phytosanitary situation of the bearing study vineyards in the two regions was favorable. The intensity of leaf injuries by the mite in those vineyards was not more than $15 \%$ per cent.

Winter pruning of canes proved to be a key mechanism to regulate the $C$. vitis numbers as it allows to eliminate the major reserve of the mites wintering in the buds. When singlearmed Guyot was used, the buds in the medium and upper portions of a cane were preserved, with potentially high numbers of the wintering population compared to bilateral horizontal cordon. In addition to mechanical regulation of the $C$. vitis numbers, sulfur was applied regularly for control of oidium in the organic and biodynamic study vineyards, without the need to rely on additional dedicated treatments while acaricidal preparations had to be applied in the traditional study vineyards.

With initially high levels of colonization by the mite, young plantings were subject to the risk of growth depression. Rootings became infested in the nurseries. Inappropriate quality of the grafting procedure aggravated the intensity of injuries of young vines by the mites and promoted their accumulation, leading to stunted cane growth. If rootings became well-established, the intensity of leaf injuries by the mite went down in the third year after planting when active growth of vines began.

Natural predatory species of mites and other insects enter as another important factor to regulate the $C$. vitis numbers. Of them, the mites of the family Phytoseiidae and the midge Arthrocnodax cf. vitis were the most abundant in the study vineyards. Despite regular sulfur application for control of oidium in the organic and biodynamic study vineyards, the predators regulated the $C$. vitis numbers effectively. 
New eco-oriented organic and biodynamic vineyards no longer relying on pesticides in protection schemes are becoming part of grape and wine growing of the Crimea, which urges a search for new solutions to reduce pests. That is why monitoring which includes both eco-faunistic research and prediction of the numbers of phytophages is becoming of primary importance in the system of control of injurious species on grapes.

\section{References}

1. H. Willer, J. Lernoud and L. Kemper, The World of Organic Agriculture, Research Institute of Organic Agriculture (FiBL), (Frick and Bonn, 356, 2019) https://shop.fibl.org/CHen/mwdownloads/download/link/id/1202/?ref=1

2. M. Volkova, E. Matveikina, J. Volkov, Organic viticulture as an important aspect of conserving biodiversity in Crimean agrocenoses, E3S Web of Conferences (INTERAGROMASH 2020), 175, 09004 (2020) https://doi.org/10.1051/e3sconf/2 02017509004

3. J. Lernoud, H. Willer, Current Statistics on Organic Agriculture Worldwide: Area, Operators, and Market, The World of Organic Agriculture. Frickand Bonn (FiBL \& IFOAM - Organics International, 2019) https://shop.fibl.org/CHen/mwdownload s/download/link/id/1202/?ref=1

4. V.V. Grigorouk, E.V. Klimov, Development of organic agriculture throughout the Globe and in Kazakhstan, 168 (Ankara, 2016) (In Russ.) http://www.fao.org/3/i545 4r/i5454r.pdf

5. The World of Organic Agriculture - Statistics \& Emerging Trends (2020) http://www.fao.org/agroecology/database/detail/en/c/1262695/

6. Organic agriculture: innovative technologies, experience, and prospects:scientifi c and analytic over-view, 92 (M.: Rosinformagrotekh, 2019) http://ksh.volgograd.ru/ upload/iblock/\%D0\%A0\%D0\%9E\%D0\%A1\%D0\%98\%D0\%9D\%D0\%A4\%D0\%9E\% D0\%A0\%D0\%9C\%D0\%90\%D0\%93\%D0\%A0\%D0\%9E\%D0\%A2\%D0\%95\%D0\%A $5 \% 20 \%$ D0\%B2\%D0\%B5\%D1\%80\%D1\%81\%D1\%82\%D0\%BA\%D0\%B0\%20organi c_cx_2019-1_copy.pdf

7. O.V. Mironenko, Meat technology, 8 (176), 38-43 (2017) (In Russ.) http://rosorganic.ru/files/Mironenko\%20Analitika\%202017-18.pdf

8. Geoffrey Jones, Emily Grandjean. Creating the Market for Organic Wine: Sulfites, Certification, and Green Values (2017) DOI:10.13140/RG.2.2.32768.53769, https://www.researchgate.net/publication/321548448_Creating_the_Market_for_Organ ic_Wine_Sulfites_Certification_and_Green_Values

9. M. Picchi, V. Canuti, M. Bertuccioli, B. Zanoni, The Influence of Conventional and Biodynamic Winemaking Processes on the Quality of Sangiovese Wine, 12, 1-16, (2020), DOI https://doi.org/10.2147/IJWR.S245183

10. Ya.A. Volkov, M.V. Volkova, E.A. Matveikina [et al.], Assessment of consumer demand for organic products in the Republic of the Crimea, Modern trends of sustainable development. International scientific conference dedicated to the memory of Academician T.S. Khachaturov, pp 30-31 (2018) (In Russ.) DOI 10.30679/22195335-2019-3-57-109-124, https://www.econ.msu.ru/sys/raw.php?o=51223\&p=attachm ent

11. E.A. Rybalko, N.V. Baranova, Monitoring systems of enviroment, 14 (34), 116-121 (2018) DOI: 10.33075/2220-5861-2018-4-116-121 
12. S.P. Korsakova, Bulletin of the State Nikitsky Botanical Gardens, (128), 100-111 (2018) (In Russ.) https://doi.org/10.25684/NBG.boolt.128.2018.13

13. Elena V. Vyshkvarkova, Evgeniy A. Rybalko, Natalia V. Baranova and Elena N. Voskresenskaya, Agronomy, 10(9) (2020) https://doi.org/10.3390/agronomy10091226

14. D.M. Rossinskii, Plant mites or hazelnut gall mites Eriophyidae 119 (M. 1909) (In Russ.)

15. Monica L. Cooper, Malcolm B. Hobbs, Becky Strode and Lucia G. Varela, Grape erineum mite: Postharvest sulfur use reduces subsequent leaf blistering https://doi.org/10.3733/ca.2020a0012

16. S. J. Khederi, M. Khanjani, M. Gholami, Exp. Appl. Acarol. 75, 1-24 (2018) https://doi.org/10.1007/s10493-018-0252-0

17. N.A. Yakushina, N.V. Aleinikova, E.S. Galkina, M.V. Volkova, Magarach. Viticulture and Winemaking, (2), 12-14 (2010) (In Russ.) https://www.elibrary.ru/download/elibr ary_23577136_16338784.pdf

18. M. Retallack, L. Thomson and M. Keller, BIO Web of Conf., 15, 01004 (2019) https://doi.org/10.1051/bioconf/20191501004

19. F. Ferragut, A. Gallardo, R. Ocete, M.A. Lopez, Vitis, 47(1), 51-54 (2008) DOI: https://doi.org/10.5073/vitis.2008.47.51-54

20. S. J. Khederi and M. Khanjani, J. Crop Prot. 3 (Supplementary), 625-630 (2014) https://www.researchgate.net/publication/283079111 